\title{
Effect of Long Term Fertilizers and Organic Manures on Key Soil Quality Indicators and Indices in Rice - Rice Cropping System
}

\author{
M. Suresh", G. Jayasree, M. Srilatha, S. Narender Reddy and G. Kiran Reddy
}

Department of Soil Science and Agricultural Chemistry, College of Agriculture, Professor

Jayashankar Telangana State Agricultural University, Rajendranagar,

Hyderabad-500030, Telangana, India

*Corresponding author

\begin{tabular}{|c|c|}
\hline \multicolumn{2}{|r|}{ A B S T RA C T } \\
\hline & \multirow{6}{*}{$\begin{array}{l}\text { A long-term experiment was conducted to evaluate the effect of integrated use of organic } \\
\text { and inorganic sources of nutrients on soil quality and its relation to rice yield under Rice - } \\
\text { rice crop rotation. A field experiment was conducted during rabi, } 2015 \text { and karif, } 2016 \text { at } \\
\text { Regional Agricultural Research Station, Jagtial (India) on an ongoing long term (16 years) } \\
\text { experiment which was initiated in kharif, 2000. Twelve treatments were laid out in } \\
\text { randomized block design with four replications. The twelve treatments were } 50 \% \mathrm{NPK} \\
\left(\mathrm{T}_{1}\right), 100 \% \mathrm{NPK}\left(\mathrm{T}_{2}\right), 150 \% \mathrm{NPK}\left(\mathrm{T}_{3}\right), 100 \% \mathrm{NPK}+\mathrm{HW}\left(\mathrm{T}_{4}\right), 100 \% \mathrm{NPK}+\mathrm{ZnSO}_{4} \\
\left(\mathrm{~T}_{5}\right), 100 \% \mathrm{NP}\left(\mathrm{T}_{6}\right), 100 \% \mathrm{~N}\left(\mathrm{~T}_{7}\right), 100 \% \mathrm{NPK}+\mathrm{FYM}\left(10 \mathrm{t} \mathrm{FYM} \mathrm{ha}{ }^{-1} \text { in kharif) }\left(\mathrm{T}_{8}\right) \text {, }\right. \\
100 \% \mathrm{NPK}-\mathrm{S}\left(\mathrm{T}_{9}\right), \mathrm{FYM}\left(10 \mathrm{t} \mathrm{FYM} \text { ha in kharif and rabi) }\left(\mathrm{T}_{10}\right) \text {, Control }\left(\mathrm{T}_{11}\right) \text { and }\right. \\
\text { Fallow }\left(\mathrm{T}_{12}\right) \text {. Soil quality assessment was done by identifying the key indicators using } \\
\text { principal component analysis (PCA) and soil quality indices (SQI). Results revealed that } \\
\text { most of the soil quality parameters were significantly influenced by the management } \\
\text { treatments in the experiment. In experiment, during rabi soil quality indices varied from } \\
1.83 \text { to } 2.41 \text { across the treatments and during Kharif season soil quality indices varied from } \\
1.74 \text { to } 2.50 \text { across the treatments. Nutrient-management treatments played a significant } \\
\text { role in influencing the SQI. Among the treatments, } 100 \% \mathrm{NPK}+\mathrm{FYM} \text { resulted in a greater } \\
\text { soil quality index ( } 2.41 \text { and } 2.50 \text { during rabi and kharif season respectively) followed by } \\
\text { only FYM treatment }(2.35 \text { and } 2.34 \text { during rabi and kharif season respectively), which was } \\
\text { at par with } 100 \% \mathrm{NPK}+\mathrm{FYM} \text {. The results indicated that the combined use of organic and } \\
\text { inorganic fertilizers maintained higher soil quality in the soil. }\end{array}$} \\
\hline Keywords & \\
\hline $\begin{array}{l}\text { Soil quality index, } \\
\text { FYM, Cropping } \\
\text { system, Chemical } \\
\text { fertilizers. }\end{array}$ & \\
\hline Article Info & \\
\hline $\begin{array}{l}\text { Accepted: } \\
23 \text { September } 2017 \\
\text { Available Online: } \\
10 \text { October } 2017\end{array}$ & \\
\hline & \\
\hline
\end{tabular}

\section{Introduction}

Soil is a key natural resource and soil quality is the integrated effect of management on most soil properties that determine crop productivity and sustainability. Good soil quality not only produces good crop yield, but also maintains environmental quality and consequently plant, animal and human health. With the advancement of intensive agriculture, soils are being degraded at an alarming rate by wind and water erosion, desertification, and salinization because of exploitative total farming practices for short term gains. Growing of crops without due consideration to total nutrient requirement has resulted in decline in soil fertility (Ghosh et al., 2003). Soil quality assessment has been suggested as a tool for evaluating sustainability of soil and crop management 
practices (Hussain et al., 1999). Rice (Oryza sativa L.) is the principal food crop of the world, contributes to about $60 \%$ of the world's food. India ranks second in rice production with 110.9 million tonnes and productivity $2.28 \mathrm{t} \mathrm{ha}^{-1}$ from an area of 39.47 million hectares.

Telangana rice production is 12.9 million tonnes and productivity $3.22 \mathrm{t} \mathrm{ha}^{-1}$ from an area of 4.01 million ha (Ministry of Agriculture, Government of India 2011). Higher production requirements for the future to meet the demands of growing population need to be achieved, maintaining the soil quality and sustainability of the productivity at the same time. Increase in cropping intensity with optimum use of production inputs like seed, water and fertilizers and effective plant production measures are the key for sustained crop yields.

In long term experiments, the treatments are applied for a long time sufficient to assess their impact on the resource base. Overall trends and cumulative impact of management systems are best studied through long term experiments. Long term experiments provide a reliable means to study the effect of continuous application of organic manures and inorganic fertilizers on the crop yields and productivity of the soil (Manna et al., 2005). The importance of long term fertilizer experiments in studying the effect of continuous cropping and fertilizer or manure application on soil quality and sustainability of crop production is widely recognised.

In India, rice is cultivated round the year in one or other part of the country. It occupies 42.8 $\mathrm{M}$ ha with a production of 95.9 $\mathrm{Mt}$ and productivity of $2.23 \mathrm{t} \mathrm{ha}^{-1}$. In Telangana and Andhra Pradesh, rice is grown in an area of 4.7 $\mathrm{M}$ ha with a production of $14.4 \mathrm{M} \mathrm{t}$ and productivity of $3.06 \mathrm{t} \mathrm{ha}^{-1}$ (CMIE, 2011).

\section{Materials and Methods}

The field experiment was conducted at Regional Agricultural Research Station, Jagtial, Karimnagar district of Telangana. The farm is geographically situated at $78^{0} 45^{\prime} \mathrm{E}$ to $79^{0} 0$ 'E Longitude and $18^{\circ} 45^{\prime} \mathrm{N}$ to $19^{\circ} 0^{\prime} \mathrm{N}$ Latitude. The climate of polasa, Jagtial was classified as subtropical. The southwest monsoon usually sets in during June-October second week giving 40-50 rainy days per year (IMD, 1978). Winter was generally milder at Jagtial and temperature begins to rise from January and reach it peak by May. Weather data were recorded at the meteorological observatory located at Regional Agricultural Research Station (RARS), Jagtial, Karimnagar district, Telangana. The present experiment is a part of All India Coordinated Research Project on Long Term Fertilizer Experiment initiated in kharif 2000-01.

The present study was taken up in 2014-15 and 2015-16 (both in rabi and kharif seasons respectively) with a view to study the effect of Long term fertilizer management on soil quality. Twelve treatments were laid out in randomized block design with four replications. The twelve treatments were $50 \%$ NPK $\left(\mathrm{T}_{1}\right), 100 \% \mathrm{NPK}\left(\mathrm{T}_{2}\right), 150 \% \mathrm{NPK}\left(\mathrm{T}_{3}\right)$, $100 \% \mathrm{NPK}+\mathrm{HW}\left(\mathrm{T}_{4}\right), 100 \% \mathrm{NPK}+\mathrm{ZnSO}_{4}$ $\left(\mathrm{T}_{5}\right), 100 \% \mathrm{NP}\left(\mathrm{T}_{6}\right), 100 \% \mathrm{~N}\left(\mathrm{~T}_{7}\right), 100 \%$ NPK + FYM (10 t FYM ha ${ }^{-1}$ in kharif) $\left(\mathrm{T}_{8}\right)$, $100 \%$ NPK $-\mathrm{S}\left(\mathrm{T}_{9}\right)$, FYM (10 t FYM ha in kharif and rabi) $\left(\mathrm{T}_{10}\right)$, Control $\left(\mathrm{T}_{11}\right)$ and Fallow $\left(\mathrm{T}_{12}\right)$.

The experimental site was a typical clayey soil. The properties of the soil before the initiation of experiment (sample collected at the initiation of the experiment i.e., before kharif 2000-01). The physico chemical properties revealed that the soil was alkaline $(8.22 \mathrm{pH})$ in reaction, non saline $\left(0.47 \mathrm{dS} \mathrm{m}^{-1}\right)$ in nature and medium in organic carbon $(0.79$ $\left.\mathrm{g} \mathrm{kg}^{-1}\right)$. The soil under study was low in 
available nitrogen (107.6 $\left.\mathrm{kg} \mathrm{N}^{-1}\right)$, medium in available phosphorus $\left(19.6 \mathrm{~kg} \mathrm{P}_{2} \mathrm{O}_{5} \mathrm{ha}^{-1}\right)$ and high in available potassium $\left(364 \mathrm{~kg} \mathrm{~K}_{2} \mathrm{O}\right.$ $\mathrm{ha}^{-1}$ ) at the initiation.

\section{Soil sampling and analysis}

Soil samples were collected during rabi and kharif from the plow layer (0.0-0.15 $\mathrm{m}$ depth) from both the experimental sites after the harvest of 2004 kharif (rainy season) crop. These samples were partitioned and passed through standard prescribed sieves for further use in a different kind of analysis. Soil samples that passed through the $8-\mathrm{mm}$ sieve and were retained on the $4.75-\mathrm{mm}$ sieve were used for aggregate analysis, while the sample that passed through the $0.2-\mathrm{mm}$ sieve was used for estimating organic carbon (OC). For the rest of the soil quality parameters such as chemical $[\mathrm{pH}$, electrical conductivity (EC), available $\mathrm{N}$, available $\mathrm{P}$, available $\mathrm{K}$, exchangeable calcium (Ca), exchangeable magnesium $(\mathrm{Mg})$, available sulfur $(\mathrm{S})$, and micronutrients such as available zinc $(\mathrm{Zn})$, iron $(\mathrm{Fe})$, copper $(\mathrm{Cu})$, manganese $(\mathrm{Mn})$, and biological dehydrogenase assay (DHA)] parameters acid and alkaline phosphates enzymes, soil samples that passed through 2 $\mathrm{mm}$ sieves were used.

Soil $\mathrm{pH}$ and electrical conductivity were measured in a 1:2.5 soil/water suspension Glass Electrode pH meter (Jackson,1967), OC by wet oxidation with sulfuric acid $\left(\mathrm{H}_{2} \mathrm{SO}_{4}\right)+$ potassium dichromate $\left(\mathrm{K}_{2} \mathrm{Cr}_{2} \mathrm{O}_{7}\right)$ (Walkley and Black 1934), available $\mathrm{N}$ by alkaline potassium permanganate $\left(\mathrm{KMnO}_{4}\right)_{-}$ oxidizable $\mathrm{N}$ method (Subbaiah and Asija 1956), available $\mathrm{P}$ by $0.5 \mathrm{M}$ sodium bicarbonate $\left(\mathrm{NaHCO}_{3}\right)$ method (Olsen et al., 1954), and available K Neutral Normal Ammonium Acetate method using Flame photometer (Jackson, 1973) and exchangeable $\mathrm{Ca}$ and $\mathrm{Mg}$ using the neutral normal ammonium acetate method. The available micronutrients $(\mathrm{Zn}, \mathrm{Fe}, \mathrm{Cu}, \mathrm{Mn})$ were extracted using DTPA $(0.005 \mathrm{M})+$ triethanolamine (TEA) $(0.1 \mathrm{M})+$ calcium chloride $\left(\mathrm{CaCl}_{2} \cdot 2 \mathrm{H}_{2} \mathrm{O}\right)(0.01 \mathrm{M})$ reagent $(\mathrm{pH}$ 7.3) as suggested by Lindsay and Norvell (1978) and determined by AAS.

Bulk density was estimated by Keen's box method, aggregate stability was measured using the wet sieve technique (Yoder 1936), and mean weight diameter (Van Bavel 1949) was calculated. Biological soil quality parameters dehydrogenase activity was found by the triphenyl tetrazolium chloride method (TTC) (Lenhard, 1956).

\section{Results and Discussion}

\section{Identification of key indicators}

After assessing the influence of the long-term conjunctive nutrient-management treatments on soil quality parameters, the data was utilized to compute the soil quality indices to ascertain the performance of the treatments in maintaining soil quality. After rabi to assess the soil quality indices of the treatments, out of the 25 soil quality parameters, 18 soil quality variables that were statistically significant were subjected to principal component analysis (PCA), whereas seven variables (viz., pH, EC, Particle density (PD), Poracity, available-K, available $\mathrm{Cu}$ and available $\mathrm{Fe}$ ) were dropped from the data set as they were not significantly influenced by the management treatments. During kharif out of the 25 soil quality parameters, 20 soil quality variables that were statistically significant were subjected to principal component analysis (PCA), whereas five variables (viz., $\mathrm{pH}$, Particle density(PD), Poracity, available $\mathrm{Cu}$ and available $\mathrm{Fe}$ ) were dropped from the data set as they were not significantly influenced by the management treatments. 
Data screening for assessment of soil quality indices (SQI)

To assess the soil quality indices after rabi season, in the PCA of 18 variables, four PCs had Eigen values > 1 and explained 69.82\% variance in the data set (Table 1). In PC1 as well as in PC3 and PC4 in each, 4, 5 and 3 variables were qualified respectively, as highly weighted variables, whereas in PC2, only a single variable has been qualified. A correlation matrix for the highly weighted variables under different PCs was run separately. In PC1, the variables qualified were Water holding capacity (WHC), Infiltration rate (IR), Hydraullic conductivity (HC) and available $\mathrm{Mn}$ which had a Correlation sum values of 2.937, 2.946, 3.009 and 2.906 respectively (Table 1) four variables were retained for the final MDS. In $\mathrm{PC} 2$, only one variable available $\mathrm{N}$, hence it was retained for the final MDS.

In PC3, among five OC, BD, IR the three highly weighted variables, available $\mathrm{S}$ and $\mathrm{Mg}$ had highly significant correlation among these two. Hence were retained for the final MDS. Hence, the final MDS included all. In PC4, the variables qualified were $\mathrm{BD}$, acid-P and $\mathrm{Zn}$. Among three acid-P and $\mathrm{Zn}$ were the highly weighted variables. Acid-P and $\mathrm{Zn}$ had highly significant correlation among these two. Hence were retained for the final MDS. Hence, the final MDS included all.

To assess the soil quality indices after kharif season, in the PCA of 20 variables, five PCs had Eigen values > 1 and explained $74.807 \%$ variance in the data set (Table 2). In PC1 as well as in PC3, PC4 and PC2 in each, 4, 4, 3 and 2 variables were qualified respectively, as highly weighted variables, whereas in PC5, only a single variable has been qualified.

A correlation matrix for the highly weighted variables under different PCs was run separately. In PC1, the variables qualified were Infiltration rate(IR), Hydraullic conductivity(HC), available-P and $\mathrm{Mn}$ which had a Correlation sum values of 2.732, 2.666, 2.441 and 2.915 respectively (Table 2 ), which was $<0.70$, and hence four variables were retained for the final MDS. In PC2, only two variables acid-p and CEC, hence it was retained for the final MDS. In PC3, among all four $\mathrm{OC}, \mathrm{BD}$, available $\mathrm{S}, \mathrm{Mg}$ highly weighted variables, these variables were retained for the final MDS. Hence, the final MDS included all. In PC4, the variables qualified were $\mathrm{BD}$, acid-P and alkaline-P.

Among three acid-P and alkaline-P were the highly weighted variables. Acid-P and alkaline-P had highly significant correlation among these two. Hence were retained for the final MDS. Hence, the final MDS included all. In PC5, only one variable EC, hence it was retained for the final MDS.

\section{Computation of Soil Quality Indices}

After selecting the key indicators (viz., OC, $\mathrm{BD}, \mathrm{WHC}, \mathrm{HC}$, IR, available $\mathrm{N}, \mathrm{S}, \mathrm{Mg}$, acid$\mathrm{P}, \mathrm{Zn}$, and $\mathrm{Mn}$ ), soil quality indices were computed. The soil quality indices varied from 1.83 to 2.41 across the management treatments in a rice-rice system during rabi season (Table 3 and Figure 1).

From the perusal of the data, it was observed that though the application of $100 \%$ NPK + FYM showed the greatest soil quality index of 2.41 , its performance was observed to be almost at par with FYM $\left(\mathrm{T}_{10}\right)$ treatment and significantly differed with other treatments. Irrespective of their statistical significance, the relative order of performance of the organic and nutrient management treatments influencing soil quality in terms of SQI was $\mathrm{T} 8, \quad 100 \% \mathrm{NPK}+\mathrm{FYM}(2.41)>$ $\mathrm{T} 10>\mathrm{T} 3>\mathrm{T} 2=\mathrm{T} 12>\mathrm{T} 4>\mathrm{T} 9>\mathrm{T} 7>\mathrm{T} 1$ and Control(T11). The average percentage 
contributions of key indicators to soil quality indices emerged in this experiment were HC, 19.52\%; WHC, $19.51 \%$; $\mathrm{Mn}, 18.42 \%$;
available-N, 7.98\%; IR, 7.5\%; BD, 6.17\%; $\mathrm{Mg}, 5.53 \%$; OC, 4.43\%; available S, 4.38\%; acid-P, 3.93\%; Zn, $2.63 \%$ (Figure 2).

Table.1 Correlation matrix for highly weighted variables under PC's with high factor loading for rabi season

\begin{tabular}{|c|c|c|c|c|c|}
\hline Variables & WHC & I.R & H.C & Mn & \\
\hline \multicolumn{6}{|l|}{ PC1 variables } \\
\hline \multicolumn{6}{|c|}{ Pearson's correlations } \\
\hline WHC & 1.00 & $0.635^{* * *}$ & $0.734^{* *}$ & $0.568^{* *}$ & \\
\hline I.R & $0.635^{* *}$ & 1.00 & $0.624^{* *}$ & $0.687^{* *}$ & \\
\hline H.C & $0.734^{* *}$ & $0.624^{* *}$ & 1.00 & $0.651^{* *}$ & \\
\hline Mn & $0.568^{* *}$ & $0.687^{* *}$ & $0.651^{* *}$ & 1.00 & \\
\hline \multirow[t]{2}{*}{ Correlation sums } & 2.937 & 2.946 & 3.009 & 2.906 & \\
\hline & Avail. N & & & & \\
\hline \multicolumn{6}{|l|}{ PC2 variables } \\
\hline \multirow{2}{*}{ Avail. N } & 1.00 & & & & \\
\hline & OC & BD & I.R & Avil.S & Mg \\
\hline \multicolumn{6}{|l|}{ PC3 variables } \\
\hline $\mathrm{OC}$ & 1.00 & $-0.369^{* *}$ & $0.670^{* *}$ & 0.000 & 0.025 \\
\hline $\mathrm{BD}$ & $-0.369^{* *}$ & 1.00 & $-0.294^{*}$ & 0.020 & 0.012 \\
\hline I.R & $0.670^{* *}$ & $-0.294^{*}$ & 1.00 & $0.308^{*}$ & $0.345^{*}$ \\
\hline Avil.S & 0.000 & 0.020 & $0.308^{*}$ & 1.00 & $0.474^{\text {** }}$ \\
\hline \multirow[t]{2}{*}{$\mathrm{Mg}$} & 0.025 & 0.012 & $0.345^{*}$ & $0.474^{* *}$ & 1.00 \\
\hline & BD & Acid -P & $\mathbf{Z n}$ & & \\
\hline \multicolumn{6}{|l|}{ PC4 variables } \\
\hline $\mathrm{BD}$ & 1.00 & -0.195 & 0.086 & & \\
\hline Acid-P & -0.195 & 1.00 & $0.418^{* *}$ & & \\
\hline $\mathrm{Zn}$ & 0.086 & $0.418^{* *}$ & 1.00 & & \\
\hline
\end{tabular}

Table.2 Correlation matrix for highly weighted variables under

PC's with high factor loading for Kharif season

\begin{tabular}{|c|c|c|c|c|}
\hline Variables & I.R & H.C & Avail.P & Mn \\
\hline \multicolumn{5}{|l|}{ PC1 variables } \\
\hline \multicolumn{5}{|c|}{ Pearson's correlations } \\
\hline I.R & 1.00 & $0.607^{* *}$ & $0.439^{* * *}$ & $0.686^{* *}$ \\
\hline H.C & $0.607^{* *}$ & 1.00 & $0.416^{* *}$ & $0.643^{* *}$ \\
\hline Avail.P & $0.439^{* *}$ & $0.416^{* *}$ & 1.00 & $0.586^{* *}$ \\
\hline $\mathrm{Mn}$ & $0.686^{* *}$ & $0.643^{* *}$ & $0.586^{* *}$ & 1.00 \\
\hline \multirow[t]{2}{*}{ Correlation sums } & 2.732 & 2.666 & 2.441 & 2.915 \\
\hline & CEC & Acid-P & & \\
\hline \multicolumn{5}{|l|}{ PC2 variables } \\
\hline CEC & 1.00 & -0.185 & & \\
\hline \multirow[t]{2}{*}{ Acid-P } & -0.185 & 1.00 & & \\
\hline & OC & BD & Avil.S & Mg \\
\hline \multicolumn{5}{|l|}{ PC3 variables } \\
\hline $\mathrm{OC}$ & 1.00 & $-.402^{* *}$ & 0.162 & 0.185 \\
\hline $\mathrm{BD}$ & $-0.402^{* *}$ & 1.00 & 0.047 & 0.023 \\
\hline Avil.S & 0.162 & 0.047 & 1.00 & $0.546^{* *}$ \\
\hline \multirow[t]{2}{*}{$\mathrm{Mg}$} & 0.185 & 0.023 & $0.546^{* *}$ & 1.00 \\
\hline & BD & Acid -P & Alkaline-P & \\
\hline \multicolumn{5}{|l|}{ PC4 variables } \\
\hline $\mathrm{BD}$ & 1.00 & -0.224 & -0.032 & \\
\hline Acid-P & -0.224 & 1.00 & $0.684^{* * *}$ & \\
\hline \multirow{2}{*}{ Alkaline-P } & -0.032 & $0.684^{* *}$ & & \\
\hline & EC & & & \\
\hline \multicolumn{5}{|l|}{ PC5 variables } \\
\hline $\mathrm{EC}$ & 1.00 & & & \\
\hline
\end{tabular}


Table.3 Effect of long term fertilizer and manure application on SQI of post -harvest soils of rice

\begin{tabular}{|l|l|l|}
\hline Treatments & Rabi & Kharif \\
\hline $50 \%$ NPK & 1.88 & 1.83 \\
\hline $100 \%$ NPK & 2.12 & 2.08 \\
\hline $150 \%$ NPK & 2.19 & 2.31 \\
\hline $100 \%$ NPK + HW & 2.06 & 2.08 \\
\hline $100 \%$ NPK + Zn & 2.11 & 2.03 \\
\hline $100 \%$ NP & 2.00 & 1.92 \\
\hline $100 \% \mathrm{~N}$ & 1.92 & 1.79 \\
\hline $100 \%$ NPK + FYM & 2.41 & 2.50 \\
\hline $100 \%$ NPK - S & 2.02 & 1.99 \\
\hline FYM & 2.35 & 2.34 \\
\hline Control & 1.83 & 1.74 \\
\hline Fallow & 2.12 & 2.06 \\
\hline S. Em. + & 0.03 & 0.028 \\
\hline CD $(0.05)$ & 0.087 & 0.080 \\
\hline
\end{tabular}

Fig.1 Graphical representation of soil quality index (SQI) values of the selected MDS variables for each treatment during Rabi season




Fig.2a Graphical representation of soil quality index (SQI) values of the selected MDS variables for each treatment during Kharif season

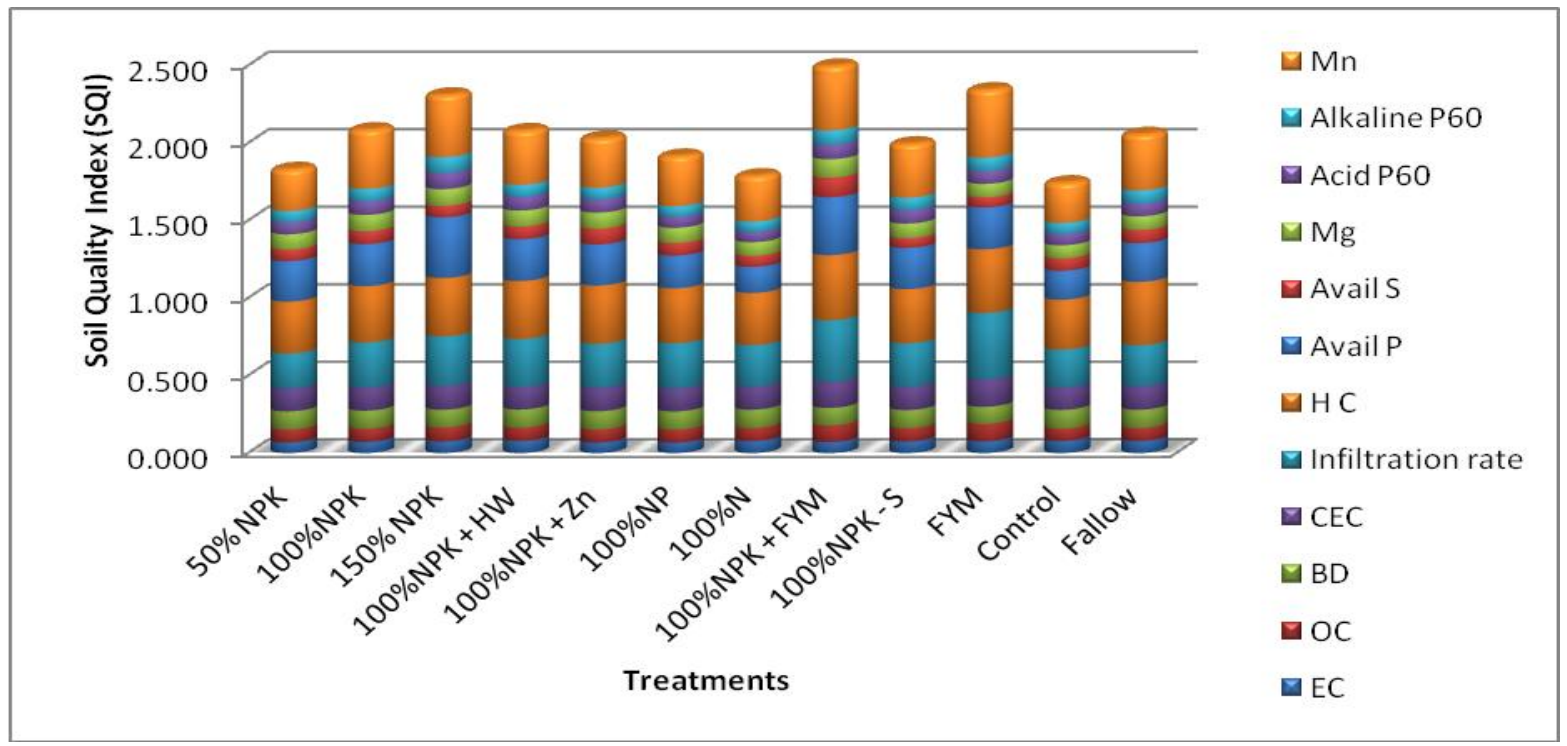

Fig.2b Percent contributions of key indicators towards soil quality indices as influenced by different soil management practices under Rice-rice cropping system during kharif season

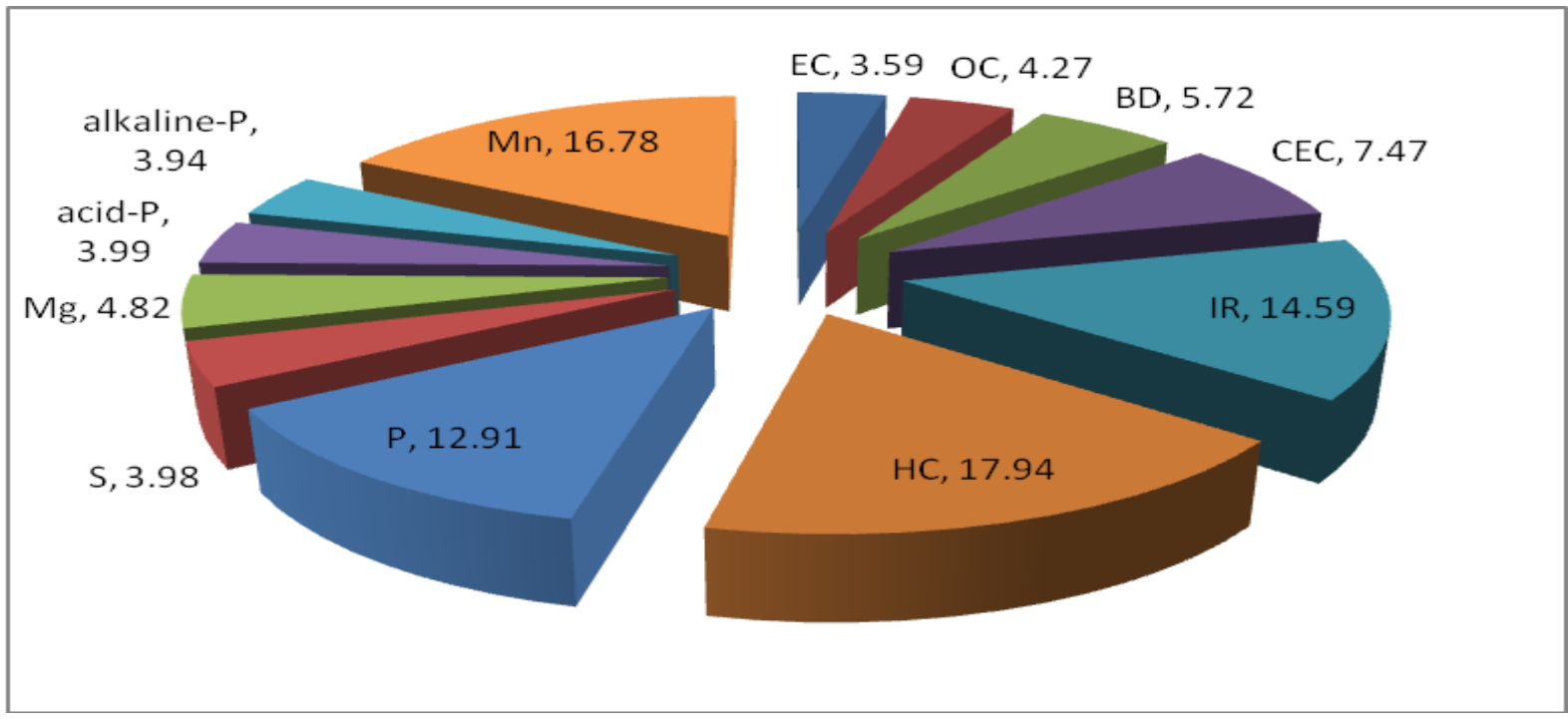

The soil quality index was found to decrease in the order of $\mathrm{NPK}>\mathrm{NP}>\mathrm{N}>$ control indicating less aggregative effect of these treatments. Increasing the fertilizer levels also helped in maintaining the higher soil quality index (1.83 to 2.41). Sharma et al., (2005) also reported that increasing levels fertilizers enhanced the soil quality index. It could be noticed that the balanced application of nutrients helped in improving the soil quality as compared to imbalanced use of nutrients.

After selecting the key indicators (viz., EC, OC, BD, CEC, IR, HC, available P, S, Mg, acid-P, Alkaline-P and $\mathrm{Mn}$ ), soil quality indices were computed. The soil quality 
indices varied from 1.74 to 2.50 across the management treatments in a rice-rice system during kharif season (Table 3 and Figure 2a).

From the perusal of the data, it was observed that though the application of $100 \% \mathrm{NPK}+$ FYM showed the greatest soil quality index of 2.50 , its performance was observed to be almost significantly differed with other treatments. Irrespective of their statistical significance, the relative order of performance of the organic and nutrient management treatments influencing soil quality in terms of SQI was T8, 100\%NPK+ FYM $(2.50)>\mathrm{T} 10>\mathrm{T} 3>\mathrm{T} 2=\mathrm{T} 4>\mathrm{T} 12>\mathrm{T} 5>\mathrm{T} 9>\mathrm{T} 6>\mathrm{T}$

1>T7 and Control(T11). Sharma et al., (2005) achieved significantly higher SQI with the incorporation of organic along with inorganic fertilizer. The average percentage contributions of key indicators to soil quality indices emerged in this experiment were HC, $17.94 \%$; Mn, 16.78\%; IR, $14.59 \%$, available-P, $12.91 \%$; CEC, $7.47 \%$; BD, $5.72 \%$; $\mathrm{Mg}, 4.82 \%$; OC, 4.27\%; acid-P, $3.99 \%$; available S, 3.98\%; alkaline-P, 3.94\%; EC, $3.59 \%$ (Figure 2b).

The indicators thus identified in the present study can be used for periodical assessment of soil quality. Appropriate management strategies can be adopted to improve these indicators. Integrated use of inorganic fertilizers and organic manure found better under the long term which enhanced soil quality in rice- rice cropping system. Organic manure (FYM) along with recommended dose of fertilizers $(100 \% \mathrm{NPK}+\mathrm{FYM})$ found to be viable options in maintenance of soil quality in long term cropping systems

\section{References}

CMIE. 2011. Executive Summary-GDP growth. Centre for Monitoring Indian Economy (CMIE) Pvt. Ltd. Mumbai. Dec, 2011.
Ghosh, B.N., Vedprakash, Kundu, S., Singh, R.D and Gupta, H.S. 2003. Distribution and buildup of oxidizable and non oxidizable soil organic carbon in soil profiles under Long term fertilizer trial in the mid hills of N-W Himalayas. Journal of the Indian Society of Soil Science.51 (3):298-301.

Hussain, I., Olson, K.R., Wander, M.M and Karlen, D.L., 1999. Adaptation of soil quality indices and application to three tillage systems in southern Illinois. Soil Till. Res. 50, 237-249.

Jackson, M. L., 1967. Soil chemical analysis. Prentice Hall of India Private Limited. New Delhi.

Jackson, M.L., 1973. Soil chemical analysis. Prentice Hall India Pvt. Ltd., New Delhi. p. 498.

Lenhard, G., 1956. Die dehydrogenaseactivitat des Bodens als Mass fur die mikroorganismentatigkeit im Boden. Zeitschrift fur Pflanzenernaehr. Dueng und Bodenkd 73:1-11.

Lindsay, W. L., and W. A. Norvell, 1978. Development of a DTPA soil test for zinc, iron manganese, and copper. Soil Science Society of America Journal 42:421-428.

Manna, M.C., Swarup, A., Wanjari, R.H., Ravankar, H.N., Mishra, B., Saha, M.N., Singh, Y.V., Sahi, D.K. and Sarap, P.A. 2005. Long term effect of fertilizer and manure application on soil organic carbon storage, soil quality and yield sustainability under sub humid and semi-arid tropical India. Field crop Research.93: 264 -280.

Ministry of Agriculture, Government of India. 2011.

Olsen, S.R., Cole, C.V., Waltanabe, F.S and Dean, L.A. 1954. Estimation of available phosphorus in soils by extraction with sodium bicarbonate. USDA Circular number 939.

Sharma, K.L., Mandal, U.K; Srinivas, K; 
Vittal, K.P.R; Mandal, B; Grace, J.K and Ramesh, V. 2005. Long-term soil management effects on crop yields and soil quality in a dryland Alfisol. Soil Tillage Res. 83:246-259. doi:10.1016/j.still.2004.08.002

Subbiah, B.V., and Asija, G.L. 1956. A rapid procedure for the determination of available nitrogen in soils. Current Science. 25: 259-260.

Van Bavel, C. H. M., 1949. Mean weight diameter of soil aggregates as a statistical index of aggregation. Soil Science Society of America Proceedings 14:20-23.

Walkley, A., and Black, C.A. 1934. Estimation of organic carbon by chromic acid titration method. Soil Science. 37: 29-38.

Yoder, R. E., 1936. A direct method of aggregate analysis of soils and a study of the physical nature of erosion losses. Journal of American Society of Agronomy 28:337-351.

\section{How to cite this article:}

Suresh, M., G. Jayasree, M. Srilatha, S. Narender Reddy and Kiran Reddy, G. 2017. Effect of Long Term Fertilizers and Organic Manures on Key Soil Quality Indicators and Indices in Rice - Rice Cropping System. Int.J.Curr.Microbiol.App.Sci. 6(10): 2727-2735. doi: https://doi.org/10.20546/ijcmas.2017.610.321 